Revista Vernáculo, nº 11-12-13, pp. 35 - 48.

\title{
As faces da gula no Inferno da Divina Comédia ${ }^{1}$
}

Emanuel França de Brito ${ }^{2}$

\section{A idéia de gula}

Ao senso estrito da palavra gula, associa-se instantaneamente à idéia de ingestão exagerada de comida e bebida; mas sob a ótica da medicina, podemos afirmar que tal exagero conduz ao acúmulo de coisas de que o corpo humano não dá conta de tirar proveito. Talvez, no mundo contemporâneo, tal palavra não seja imediatamente ligada à idéia de pecado, já que hoje a prática do exagero não seria tão condenável se levada em conta a inúmera quantidade de recintos espalhados nas mais diferentes localidades que se propõem a receber pessoas dispostas a comer e beber até se fartar, sempre com o aval da sociedade de maneira geral.

Contudo, nos últimos 20 séculos, pelo menos, falar em gula era necessariamente se remeter a algum preceito ético ou religioso referente à cultura do mundo ocidental, principalmente pela perspectiva do termo “pecado”. Isso talvez pela proximidade que o ato de comer, exageradamente e bem, mantenha com a idéia de prazer, até mesmo daquele sexual. Mas desde os tempos mais remotos, naqueles em que eram produzidos os escritos que serviram de fundamento para a formação cultural do ocidente cristão, discute-se sobre os limites do prazer, seja ele em relação ao alimento ou de qualquer outra espécie. Trata-se da antigüidade grega clássica e das contribuições feitas por seus filósofos, principalmente Platão e Aristóteles.

Dentre as obras de Aristóteles, cabe aqui pegar como ponto de partida para conceituação da idéia de gula a obra Ética a Nicômaco, na qual o filósofo discorre sobre os valores dos princípios éticos e morais que regem a conduta dos homens e na qual procura ordenar as virtudes humanas e contrapô-las aos vícios que assolam a nossa raça. Sobre os vícios, os quais são considerados os extremos opostos das virtudes equivalentes, Aristóteles os dividiu em grupos, sempre de acordo com a gravidade e a intencionalidade.

Recomecemos agora a nossa investigação [em torno das virtudes] tomando outro ponto de partida e salientando que as disposições morais a ser evitadas são de três espécies: o vício, a incontinência e a bruteza. (...) Agora devemos falar da incontinência e da moleza (ou efeminação), e de seus contrários: a continência e a fortaleza; pois cumpre tratar de ambas como não idênticas à virtude ou à maldade, nem como um gênero diferente. (...) Trataremos de provar, se possível, a verdade de todas as opiniões comuns a respeito desses afetos da mente ou, se não de todas, pelo menos do maior número delas e das mais autorizadas. (ARISTÓTELES, pág. 357)

Para a gula, assim como para a desmedida sexual, foi adotado o conceito de incontinência, ou seja, falha em se conter diante daquilo que seria indispensável à natureza dos homens, nesses casos a sobrevivência e a reprodução da espécie humana. No entanto, a afirmação de que tais inclinações ao exagero não seriam necessariamente boas ou más nos remete à interpretação de que a doutrina Católica preferiu vê-las sob a ótica negativa, como uma tentação do adversário de Deus. Isso porque Aristóteles foi também um dos grandes influenciadores da formação da doutrina da primeira igreja cristã, sendo lido, anotado e estudado por grandes doutores dessa igreja como Santo Agostinho e São Tomás de Aquino.

A partir disso, pela maneira imperativa com a qual a Igreja Católica conduzia seus fiéis, o imaginário ocidental cristão foi levado a observar o exagero e tudo aquilo relacionado aos vícios humanos sob uma perspectiva pejorativa e maniqueísta, embasando-se na classificação dos vícios morais feitos por Aristóteles, mas aos quais preferiu denominar pecados.

Mais do que proporcionar a continuidade da vida, o alimento é tido pelo homem, tanto o moderno como o antigo e o medieval, uma fonte de prazer. Com isso, alimentar-se passa a não ser mais somente uma necessidade fisiológica, mas também uma busca por prazer. Contudo, sabe-se que existe por trás da doutrina Católica a negação do prazer carnal, mundano, por estar este relacionado ao pecado - ficando reservado o reino dos céus aos que souberam se abster do prazer físico e buscaram uma iluminação intelectual e espiritual. Mesmo que para fundamentar a concepção de pecado os pensadores católicos tenham ido buscar suas fontes em filósofos clássicos como Aristóteles, que não negava o prazer e sim o aconselhava comedidamente.

Contudo, nos dias atuais, nos quais estamos todos sujeitos a sermos vistos e analisados sob a ótica da psicologia e todas as suas explicações acerca do comportamento humano, ter em mente que a compulsão por comida pode ser fruto de uma "autoflagelação", ou de uma "transferência”, na qual procuramos compensar

\footnotetext{
${ }^{1}$ Versão da Monografia a ser apresentada como quesito parcial à obtenção do Título de Bacharel em Literatura Italiana.

${ }^{2}$ Graduando em Letras pela UFPR.
} 
nossas perdas através do exagero de outras coisas, torna-se um pouco perigoso quando é proposto que seja estudado o comportamento de homens e mulheres da Idade Média. E é esse o caso do presente estudo, deixar de lado os valores psicoterápicos atuais pela distância temporal com a época de Dante. Ainda também porque Dante acreditava na fraqueza dos homens, não dotados da luz da razão, a resistir aos bens terrenos; fraqueza proveniente da falta de conhecimento do poder divino e, com isso, mais vulnerável às tentações do Diabo. Portanto, não cabe aqui analisar a gula da Divina Comédia como falha da psicologia humana, mas sim como fruto da tentação maléfica do Diabo católico pela sua capacidade de dominar a mente daqueles que não se aproximaram do conhecimento divino. Também porque a tradição intelectual da Idade Média à qual pertencia Dante era fundamentalmente teológica e maniqueísta.

Porém, para que a idéia de gula que proponho pensar refletida dentro da obra Divina Comédia se concretize, é necessário que seja ampliada a questão e considerada também a hipótese de que o homem, seja este de que época for, pode querer devorar exageradamente outras coisas além da comida necessária à nossa existência. A noção de que a mente humana é assaltada por uma fome insaciável de pensamentos, sensações e conhecimentos é a imagem mais clara de quanto o espírito do homem medieval estaria vulnerável a essas “tentações” colocadas pelo Diabo. Resta saber e discutir até que ponto se pode e se quer saciar essa fome já que o que fica evidente, pensando o espírito humano, é que essas nossas “vontades” nunca têm fim.

Além da fome, a idéia pode se ampliar para uma sede de devorar e digerir o mundo através do conhecimento desse mundo. Aqui, mais um exemplo de como o que entendemos como gula pode se transformar em outros pecados. Desta vez a vaidade, a soberba provocada pelo "poder" de ter conhecimento de mundo.

O clima da gula é chamado, pela tradição filosófica, de "idealismo”. (...) O conhecimento é definido, inclusive pelos chamados “materialistas”, como transformação da matéria em mente. Ou, como dizem os marxistas, como "progressiva humanização da natureza”. É, portanto, guloso esse tipo de pensamento; e neste sentido é idealista. (FLUSSER, pág. 121-122)

Com isso, apesar das referências temporais da citação acima, as quais não é a intenção aqui considerar, pode-se entender o fluxo da natureza humana direcionado à tentativa de dar conta do mundo e torná-lo real através do conhecimento desse mundo, seja tal conhecimento de qualquer uma das áreas sistematizadas da nossa tradição intelectual; conhecimento o qual estamos fadados a ir constantemente buscar, vista a nossa natureza "gulosa” de novas experiências. Mas para que este conhecimento se concretize é necessário o impulso da própria sede de ter domínio do mundo em questão.

É sabido que Dante, quando se propôs a escrever a Divina Comédia, intuiu discorrer acerca dos vícios humanos e dos caminhos da humanidade. Mas o que é mais importante, intuiu dar conta do espírito humano e sua natureza ambígua através da representação do inferno, purgatório e paraíso. Para tanto, é relevante considerar que Dante pensou os pecados além daquelas clássicas imagens medievais, nas quais o homem é vítima do seu próprio vício representado pelo demônio. É de se pensar que Dante via tais homens como vítimas, mas principalmente das suas próprias fraquezas de intelecto e de seus espíritos, que não buscaram a luz concedida àqueles que a buscam através do saber intelectual e da razão espiritual; apesar de se crer que o autor aqui em questão concebia os pecados através da tradição católica, mas para que houvesse um afastamento desses pecados era necessária a busca da iluminação, ou seja, o uso da razão espiritual e intelectual para aproximação de Deus, nesse caso o cristão. Aproximação que se dá a partir do momento em que o homem, por conhecimentos filosóficos e teológicos, atenta para a importância das suas ações e de como elas refletem para a salvação de suas almas.

Por outro lado, permanece a idéia de que o motivo que impulsiona o homem "pecador” a buscar tal iluminação é primeiramente a ânsia, a gula de querer poder abarcar certo conhecimento, que por uma lógica e por um direcionamento Católico pode conduzir a Deus. Mas isso dependerá da conduta de quem procura por esse conhecimento e da disponibilidade que essa pessoa dá ao intuito de atingir a razão divina pregada pela Igreja. A exemplo dos próprios filósofos gregos influenciadores da doutrina Católica, Aristóteles e Platão. Para Dante, foram os dois os expoentes máximos da intelectualidade humana, mas por sua falta de fé na vinda do salvador - representado no mundo ocidental por Jesus Cristo - foram condenados dentro da Divina Comédia a vagar pelo limbo do Inferno.

Olhando um pouco à frente vi o imortal

mestre de todo homem de saber

sentado em reunião filosofal.

Honrarias todos vão lhe oferecer;

Sócrates vejo entre eles e Platão,

Mais próximo que os outros, a o entardecer. 
(DANTE, Inferno: Canto IV, versos 130-135)

A idéia de incontinência definida por Aristóteles reflete que algum limite foi ultrapassado. Para compactuar com os ensinamentos da Igreja, esse limite deve ser acerca do sexo ou da comida para caracterizar os pecados da gula e da luxúria. Porém, não seriam também as idéias de fraude ou malícia relativas ao abuso da razão e, assim, caracterizando um tipo de incontinência? Vale lembrar que a tal incontinência é entendida como fraqueza moral sem premeditação, mas o simples fato de não ser capaz de conter a premeditação também pode caracterizar um tipo de incontinência, a moral.

Chega-se ao ponto principal da discussão, gulas diferentes com conseqüências físicas diferentes. Ao primeiro tipo de gula, aquele tradicional: come-se e bebe-se desmedidamente e a conseqüência será sempre negativa e passível de punição pelo consenso da incontinência. A outros tipos de gula - de conhecimento ou espiritual, a serem ainda melhor explicitadas - aplica-se a lógica teológica, segundo a qual é preciso existir fé para que não sejam condenáveis.

\section{A gula física}

É a partir do terceiro círculo do Inferno da Divina Comédia (Canto VI) que aparecem, com a acepção mais ortodoxa do termo, os gulosos. Acepção ortodoxa no sentido de ser aqui aplicado o intento denotativo da palavra, ou seja, gula interpretada como excesso na comida e na bebida e como apego exagerado às boas iguarias.

Neste capítulo, retoma-se a definição do pecado da gula através da separação entre os vícios humanos feita por Aristóteles e, posteriormente, adotada pela filosofia católica a partir de reflexões de alguns de seus maiores pensadores. Aplica-se o rótulo da incontinência, adotado pelo filósofo grego, ao tipo de gula pelo qual são punidas as almas que se encontram neste terceiro círculo. Isso porque essas tais almas não conseguiram se afastar dos bens e dos prazeres mundanos obtidos através da comida e da bebida e, portanto, não souberam se conter diante daquilo que foi designado aos seus corpos, em vida, como um meio de sobrevivência.

É certo que devemos considerar o fato de que no período medieval, dentro do qual se compreende a Divina Comédia, o ato de comer exageradamente estava relacionado a uma atitude nobre. Nobre não no sentido de louvável, mas sim de estar diretamente ligado ao comportamento de aristocratas. E nesse intento, o de comer sem limites, não era considerada a ética cristã, mas sim contrariada.

O episódio relatado por Liutprando de Cremona no século $\mathrm{X}$, segundo o qual se recusou a coroa de rei dos francos ao Duque de Espoleto por causa de seu apetite muito fraco ("não é digno de reinar sobre nós aquele que se contenta com uma pequena refeição"), é emblemático de uma realidade social e cultural na qual o alimento estava revestido de uma função semiótica bem precisa. (MONTANARI, pág. 38)

Mas não que pelo fato de tais atitudes estarem relacionadas aos nobres fossem elas mais do que simplesmente aceitas pela sociedade em geral. Pelo contrário, por se tratar de um período no qual as técnicas de agricultura ainda estavam sendo aprimoradas e a caça era restrita, era normal que o alimento fosse escasso à mesa do cidadão medieval comum. Sem contar que a abundância de comida era concedida somente aos ricos, muito provavelmente invejada pelos cidadãos que não tinham acesso a ela ${ }^{3}$.

A gula, desde quando analisada pelos pensadores citados, sempre foi considerada e condenada como um crime individual por fazer mal somente àquele que a comete e pelo pecado estar em "venerar o próprio ventre como a um Deus” (PROSE, pág. 17). É de se crer, no entanto, que Dante poeta a julgava sob uma outra perspectiva, vista a maneira coletiva como cumprem suas penas os culpados pela gula no Inferno de sua Comédia.

Porque a culpa da gula me danou

como me vês, nesta chuva me achaco

co’as tristes almas que estão, como estou, condenadas a pena semelhante

\footnotetext{
${ }^{3}$ Existem relatos de canções medievais como a que descreve o país imaginário chamado “Cocanha”, no qual o alimento nunca acaba e para o qual as pessoas não precisam fazer nenhum esforço senão o de esticar o braço e alcançar o que se deseja. O que nos leva a crer que a quantidade de comida presente à mesa da população medieval em geral era bem mais escassa do que aquela a qual se idealizava, fazendo com que fossem sonhadas quantidades ilimitadas. Ver FRANCO Jr. Cocanha: A história de um país imaginário. $1^{\text {a }}$ Edição. São Paulo: Companhia das Letras, 1998. Pág. 26.
} 
por semelhante culpa.[... $]^{4}$

(DANTE, Inferno: Canto VI, versos 53-57)

Mas pensando uma dada sociedade, entende-se que a moralidade coletiva pudesse efetivamente ser prejudicada com os excessos de um glutão. É o caso da afirmação de Montanari a seguir, na qual é mencionada a condenação da gula. Com isso, define-se também o vício da gula como um desvio moral, ou seja, através do qual o conjunto das regras comuns tidas como verdadeiras por um determinado grupo seja molestado pelo comportamento de um dado cidadão. Interpreta-se que outras pessoas podem vir a ser prejudicadas com a falta de alimento gerada pelo exagero de alguns.

Enfim, não se deve esquecer as componentes simbólicas e ideológicas da alimentação: a comunhão, a freqüência dos jejuns, a condenação da gula, da indigestão e da embriaguez, com a julce estando ligada à luxúria e provocando pesadelos. (MONTANARI, pág. 38)

Aqui se encaixa o personagem adotado dentro da Divina Comédia como modelo de guloso, o qual foi condenado a cumprir sua pena no terceiro círculo do Inferno. Trata-se de Ciacco, cidadão da cidade de Florença contemporâneo a Dante, que em vida aproveitou abusivamente dos prazeres da comida, mas em contrapartida sofreu com o julgamento de seus concidadãos. Isso se constata pelo apelido recebido, Ciacco, que em língua fiorentina de então (meados do século XIII) significava “porco" e aparece na Divina Comédia como único meio pelo qual tal personagem foi conhecido, visto que seu nome foi ocultado por Dante autor, apesar de especulações acerca do nome do poeta fiorentino Ciacco dell’Anguillara.

A partir das idéias difundidas pelos bestiários medievais, é de se notar que o valor simbólico do porco para o homem há muito está em discussão. Outro caso é a Bíblia, que menciona várias vezes o caráter ambíguo da alimentação deste animal (Lev 11,7 e Dt 14,8), sendo considerado imundo e impuro pelo Antigo Testamento ${ }^{5}$.

Com isso, o julgamento moral feito por parte da população da Florença contemporânea a Dante em torno do nome do glutão Ciacco pode ser analisado e interpretado a partir do conhecimento popular que estava e está enraizado no dogma católico, segundo o qual nos transformamos naquilo que comemos assim como aquilo que comemos se transforma em nós.

A Eucaristia é um ato antropofágico: um ritual mágico. Os convidados comem o corpo de uma pessoa morta a fim de se tornar semelhantes a ela. É a comida (e não os participantes) que executa a transformação alquímica. Se a carne e o sangue da vítima forem assimilados a nosso corpo, eles se tornarão o que somos, e nós permaneceremos os mesmos. Mas se, ao contrário, a carne e o sangue nos devorarem e nos assimilarem, ficaremos semelhantes a eles: o corpo e o sangue de Cristo. (ALVES, pág. 34-35)

Dada a diferença simbólica existente entre a imagem do porco da qual estamos tratando e a do Cristo da citação, na qual uma tende ao negativo e outra é o extremo positivo da redenção humana, não se pode negar que a concepção de que nos transformamos naquilo que comemos é relevada pela doutrina católica, que Dante seguia assim como a maioria de seus concidadãos. Ainda hoje isso pode se realizar a partir da interpretação de ditados de domínio público contemporâneos, a exemplo "Nós somos aquilo que comemos".

Portanto, considerar Ciacco e os outros glutões punidos dentro do terceiro círculo do Inferno como porcos por terem eles comido vorazmente a carne desse animal, ou puramente por terem eles comido com o apetite e a voracidade desse animal, seria compreensível dentro do imaginário cristão ocidental que está sendo estudado $^{6}$. Isso considerando que a doutrina Católica não condena o consumo desse tipo de carne como a Hebraica.

\footnotetext{
4 Tal afirmação de que o culpado, no caso o personagem Ciacco, não está sozinho se confirma de uma forma mais clara no texto original do que na tradução: $E$ io anima trista non son sola [...].

${ }^{5} \mathrm{O}$ porco, apesar de estar de acordo com as classificações alimentares impostas pelo livro dos hebreus e dos cristãos, na qual os quadrúpedes devem ter o casco fendido em duas unhas para que sejam considerados puros, não é necessariamente herbívoro e não rumina, ou seja, não mastiga de novo a erva que já engoliu. Considerando o fato de que também se distingue dos seus semelhantes por comer carne possa ter contribuído para que o juízo moral dos homens o considerasse guloso.

${ }^{6}$ É de se considerar que além do imaginário ocidental, a idéia de incontinência alimentar também possa estar associada à figura do porco na tradição oriental. Ver o filme em forma de animação A Viagem de Chihiro, no qual os pais da

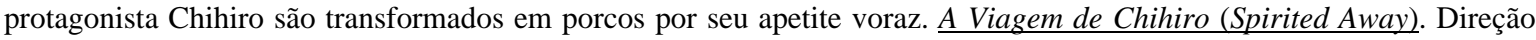
de Hayao Miyazaki. Japão, 2001.
} 
Dante poeta ilustrou com uma chuva incessante, pesada e fria a pena à qual estariam sujeitas aquelas almas apegadas aos prazeres terrenos; chuva essa que apodrece a terra na qual devem rolar essas almas pecadoras. É interessante observar aqui a aproximação com a terra que faz o poeta para punir os incontinentes. Com base na Lei do Contrapasso ${ }^{7}$ como uma forma para punir os culpados do seu Inferno e, por conseguinte, os culpados pela gula, aqui o prazer obtido pelos sentidos do olfato e do paladar é provocado e contraposto ao nojo e à repugnância causados pelo horror da terra podre que a chuva remove e ajuda a apodrecer.

No círculo terceiro estou; maldita

eterna chuva, gélida e pesada

em monótono ritmo precipita.

Grosso granizo, neve, água inquinada

pelo ar tenebroso se reversa

fede a terra por eles encharcada.

(DANTE, Inferno: Canto VI, versos 7-12)

A imagem de almas que pagam os seus pecados rolando e penando na lama é bastante associável à imagem de porcos que se revolvem e se atolam dentro dos chiqueiros. A partir disso, é de se atentar à natureza do comportamento dos porcos e de como os homens a interpretam há muito tempo: como um animal sujo e guloso, digno de receber como alimento sempre o que há de menos nobre pela sua inferioridade e gula; o qual está sempre disposto a comer e se fartar com aquilo que o homem rejeita.

O cão voltou ao seu próprio vômito; e: A porca lavada voltou a revolver-se no lamaçal. (BÍBLIA, 2Pd. 2,22)

Temos aqui explorada pela citação bíblica uma idéia de retorno. Retorno que pode ser entendido como à essência da própria natureza do animal; continuar aquilo para o que se está programado, para onde conduz o instinto. Portanto, considerada a semelhança da natureza dos dois animais citados, o porco e o cão, seria natural que uma porca depois de limpa voltasse à sua essência “imunda”; e que um cão, depois de expelir aquilo que seu organismo rejeitou, comesse novamente o expelido, dada a sua natureza gulosa.

Além da Bíblia, os bestiários também afirmam a natureza gulosa do cão, imagem na qual também Dante se apóia para ilustrar o demônio do terceiro círculo do Inferno.

Outra propriedade do cão é que come de novo o que vomita pela boca. (LIBELLUS, tópico 39)

O círculo dos gulosos é guardado pelo cão mitológico de nome Cérbero. Trata-se de uma besta feroz de três cabeças caninas e cauda de serpente (GUIMARÃES, pág. 103), que se assemelha mais - sob o olhar crítico do narrador Dante - a um verme, pelo lugar onde se encontra, o qual uiva e atormenta com as três bocas, para o desespero dos pecadores que se encontram neste círculo.

Cérbero, fera monstruosa e perversa,

caninamente co' as três goelas late

para a gente que está na lama imersa;

(DANTE, Canto VI, versos 13-15)

Dante não é o primeiro a fazer referência a esse personagem mitológico, o qual aparece em outras obras da literatura clássica como um animal guloso. A exemplo da obra Eneida, escrita pelo poeta latino Virgílio que na Divina Comédia, dentro das câmaras do Inferno e do Purgatório, faz as vezes de guia de Dante.

É explicita e claramente assumida por Dante a influência sofrida na leitura da Eneida de Virgílio. Isso porque, assim como no poema clássico latino, na Divina Comédia existe uma viagem à cidade de Dite, tal cidade com o mesmo valor simbólico negativo e infernal para as duas tradições dos dois poetas - a latina pagã e a cristã.

A partir da viagem feita por Enéias, herói da narrativa clássica, Dante recolheu experiências a serem narradas na sua própria viagem, agora como narrador/herói e não apenas como leitor. A exemplo de sua passagem junto a Virgílio - este agora sob o encargo de guia propriamente dito e não mais somente como tutor intelectual do herói Dante - pelo cão guardião do círculo dos gulosos.

\footnotetext{
${ }^{7}$ Critério de punição a partir do qual toda pena é aplicada com similaridade ou distanciamento das transgressões terrenas de maneira a relembrar constantemente os espíritos das faltas ou excessos praticados em vida.
} 
Assim como na Eneida, na Divina Comédia existe uma tentativa por parte de Cérbero de impedir que os viajantes Virgílio e Dante atravessem o terceiro círculo. Neste ponto, da mesma maneira que conta Dante com a experiência do poeta Virgílio, que na função de protetor lança um monte de terra podre para instigar a gula e a atenção de Cérbero, Enéias tem a seu lado a virgem sacerdotisa Sibila que por sua vez conta com um outro artifício para o mesmo propósito.

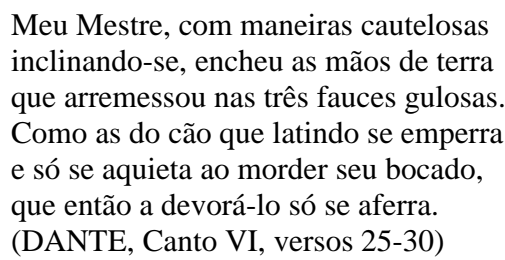

A sacerdotisa, vendo já seu pescoço se eriçar de serpentes, lança-lhe um bolo soporífero composto de mel e de grãos preparados; o animal, com fome devoradora, abre suas três goelas e engole o que lhe lançam, estende-se no solo e com seus costados imensos enche todo o antro. (VIRGÍLIO, Livro Sexto, pág.128)

Em ambas as narrativas, os viajantes obtiveram êxito nos seus propósitos, ou seja, despertaram os instintos da besta gulosa e foram capazes de passar por ela durante o seu momento de distração e sedução provocado pelo "alimento" recebido. No primeiro exemplo, temos a imagem de uma besta cega que se deixa enganar, mais pelo gesto da ação de Virgílio do que propriamente pelo sabor daquilo que estava recebendo. Já no segundo exemplo existe uma premeditação por parte de Sibila, que prepara um quitute com a capacidade de fazer dormir a besta.

Mesmo que em um primeiro momento não se associe comportamentos humanos refletidos em bestas, sendo estas literárias são passíveis de interpretação. Sendo assim, pode-se projetar no comportamento do Cérbero da Divina Comédia, aquele que não esteve sujeito a uma intenção pré-concebida por parte dos viajantes Virgílio e Dante, uma atitude semelhante à que teria um homem depois de ingerir uma quantidade de alimento não necessária à sua sobrevivência, ou seja, um momento de perda de sua sagacidade e de sua esperteza. Momento este acompanhado de um instante de gozo e um retardamento, que no caso da fera permitiu a passagem dos heróis da narrativa. Aplica-se aqui, portanto, a idéia da não-necessidade de comida por estar a besta em um plano infernal, no qual não existe a obrigatoriedade da ingestão alimentar para que se mantenha a existência.

Sobre tal retardamento, apesar de mais freqüentemente aplicado aos seres humanos do que a bestas mitológicas pela profundidade psicológica, fez menção São Tomás de Aquino quando enumerou, em seus escritos sobre os sete pecados capitais, as “cinco filhas” que o excesso de comida pode gerar.

Há certos vícios, as filhas da gula, que nascem da gula e podem se seguir a um prazer desregulado no comer e no beber. [...] Em primeiro lugar, quanto à razão, cuja agudeza se torna obtusa pelo excesso de quantidade ou de solicitude no comer, pois quando se perturbam as potências inferiores corporais pelo consumo desordenado de alimentos também a razão fica obstruída e, assim, o embotamento da inteligência é considerado filho da gula. (TOMÁS DE AQUINO, pág. 105)

Fala-se, contudo, na perda da agilidade da inteligência quando se come em quantidade exagerada. No entanto, a questão física humana que está sendo tratada vai um pouco além. Devemos nos espelhar nas nossas sensações físicas para que a prática do exagero não ocorra, pois, assim como Santo Agostinho se lamentou por sua fraqueza diante da comida ${ }^{8}$, nem sempre é claro quando se atinge o ponto da saciedade e se pode abandonar aquilo que se está ingerindo.

Isso, porque o excesso de comida ingerida não se aplica a nenhuma função. Come-se demasiadamente apenas pelo prazer do exagero, não se dando nenhum fim a toda a quantidade consumida além do necessário que não o acúmulo no próprio corpo. E dentro das concepções éticas usadas como base para a presente pesquisa - que provavelmente foram as mesmas utilizadas por Dante quando classificou e dividiu seu Inferno - o exagero não deve ser cometido se não se pode fazer uso daquilo que está sendo acumulado, uma vez que o exagero conduz ao acúmulo. Portanto, gula como ingestão exagerada de alimento é passível de condenação sob a ótica de Dante, já que os gulosos em questão comeram, comeram e comeram só pelo seu próprio prazer e bem estar físico e não com o intento de destinar este excesso a algum fim cristão.

\footnotetext{
${ }^{8}$ AGOSTINHO, Santo. Confissões. 9a Edição. São Paulo: Paulus, 1984. pág. 281 e 282.
} 


\section{A gula intelectual}

Cabe agora falar de um outro tipo de gula, a de conhecimento. Antes de qualquer coisa, é necessário que seja retomada a essência daquilo que foi discutido como gula e, principalmente, daquilo que foi proposto como possíveis representações de gula. Nesse sentido, a idéia de que tal vício é visto sob o prisma da incontinência permanece intocada, já que tal conceito aborda a gula de uma maneira global, ou seja, o ato de comer, de apoderar-se da comida sem continência. Ainda nesse sentido, devemos ampliar a questão e projetar aquilo que entendemos como incontinência para além das necessidades humanas tradicionalmente relacionadas a esse assunto: a fome e a procriação da espécie, que podem se relacionar com a gula e a luxúria.

Para tanto, é preciso que aquilo que convencionalmente se classifica como incontinência, ou ausência de limite, ultrapasse a já citada e debatida relação com a alimentação e o sexo e se projete também em outros aspectos existentes dentro do leque de vontades humanas, sejam estas imprescindíveis ou não.

Mas se levarmos em conta o que já foi pensado sobre a natureza da alma humana ${ }^{9}$ e de como esta se diferencia das almas dos animais e dos vegetais, é compreensível que se veja como gula o apego exagerado ao conhecimento ${ }^{10}$, já que se conclui que o que diferencia o homem dos outros seres vivos é o fato de aquele possuir uma alma racional, com necessidades intelectuais além das físicas. É através deste viés que a gula interpretada como vontade exagerada de conhecimento, de sabedoria pode também ser lida como incontinência.

Aqui se apresenta uma questão delicada. Qual seria o limite do conhecimento para que não seja condenável frente à ética cristã? Se for pensada a maneira já mencionada com a qual Santo Agostinho mostra suas fraquezas diante daquela gula física, a de comida, a incontinência pode ser condenável por sua falta de destino final, já que o que se come em excesso é acumulado e não aproveitado. E esta é exatamente a mesma linha de raciocínio que segue Dante para se pensar e condenar a gula de conhecimento.

É sabido que a Divina Comédia foi escrita em um contexto no qual a racionalidade era extremamente cristã, segundo a qual para estar de acordo com aquilo que se concebia como verdade era necessário entender o mundo como uma criação única e exclusivamente divina, estando a natureza e tudo o que nela se insere subordinados à vontade de Deus. Para isso, acreditar na Bíblia e parafrasear preceitos bíblicos era essencial.

Esse primado de ato de confiança produz uma oposição duradoura entre a fé e o saber, apoiada nas formulações de São Paulo, incessantemente repetidas e glosadas ao longo da Idade Média: a verdade divina só se deixa conhecer “através de um espelho”, através de “enigmas”. (BOUREAU, pág. 413)

Também para Dante, só a razão é capaz de mostrar que Deus vai muito além da razão. Com isso, através do viés dantesco, assim como católico, pode-se entender legítima a busca pelo conhecimento quando se trata de um conhecimento destinado à fé, que pode ampliar a visão de mundo daquele que o procura exageradamente para que toda essa racionalidade seja conduzida - necessariamente - a Deus. Como faz menção o tópico destinado à noção de aspecto subjetivo de pecado, encontrado na Enciclopédia Católica, quando discorre sobre a importância em adquirir conhecimento para melhor formar a consciência.

Retomando a análise do pecado, sabe-se que norma imediata de conduta é a consciência, ou seja, o julgamento que uma pessoa faz acerca da moralidade da sua ação. O pecado é, portanto, um ato livre contra a própria consciência. Mas a consciência pode também estar em desacordo com a norma objetiva de conduta (fim, vontade divina). [...] Isso torna mais clara a importância em agir de acordo com a própria consciência e em fazer força para formar tal consciência cada dia melhor. Nisso está todo o valor moral do homem e, portanto, a única base universal para a salvação ${ }^{11}$. (CITTÀ DEL VATICANO. Tomo IX, pág.1021)

\footnotetext{
${ }^{9}$ Assim como Aristóteles na obra De Generatione Animalum, vários foram os pensadores desta questão. Mas a grande diferenciação que se faz a respeito dos tipos de alma é acerca de suas naturezas, entenda-se: alma "vegetativa”, destinada ao tipo de vida vegetal, ou seja, das plantas; alma "sensitiva", a dos animais em geral, que seguem os seus instintos; e alma "intelectual”, a dos homens, desejosa de saber. Ver ALIGHIERI, Dante. Purgatorio. In La Divina Commedia. $2^{\mathrm{a}}$ Edizione. Commenti di Daniele Mattalia, pág 454. Milano: Rizzoli Editore, 1981.

${ }^{10}$ Disso surgem expressões populares como "devorar um livro".

${ }^{11}$ Tradução minha de "Riprendendo di nuovo l’analisi del peccato, si sa che norma immediata di condotta è la coscienza, ossia il giudizio che uno ha sulla moralità della sua azione. Il peccato è quindi un atto libero contro la propria coscienza. Senonché la coscienza può anche essere difforme dalla norma oggettiva di condotta (fine, volontà divina). [...] Ciò rende più chiara l'importanza per ciascuno dell'agire secondo la propria coscienza e dello sforzarsi per formarla ogni giorno di più. In questo sta tutto il valore morale dell'uomo e quindi l'unica universale base per la salvezza."
} 
Aqui entra em questão a maneira como Dante escolheu punir o herói clássico grego Ulisses dentro da Divina Comédia, como um conselheiro fraudulento. Acontece que tal herói é amplamente conhecido, tanto antes quanto depois da escrita da Divina Comédia, por suas aventuras durante a guerra de Tróia narradas na Ilíada de Homero, assim como pela temporada de retorno à sua cidade natal encontrada na epopéia Odisséia, também do autor Homero. Mesmo assim, Dante não hesita em usá-lo como exemplo para a criação da imagem de uma chama que queima em seu interior aquele que conduziu à morte seus companheiros.

[...] “Lá sofrem essa pena dira

Diomedes e Ulisses: juntamente

à pena vão como a arrostada ira:

dentro daquela chama se ressente

o logro do cavalo, que foi porta

pra a dos romanos garbosa semente;

(DANTE, Inferno: Canto XXVI, versos 55-60)

Mas devemos entender o porquê de ser Ulisses condenado ao círculo de Malebolge, o dos fraudulentos. Antes de tudo, Virgílio quando esclarece ao Dante viajante a imagem da chama de fogo, dentro da qual são punidos Ulisses e Diomedes, remete à fraude do cavalo de Tróia, do qual foi mentor o próprio Ulisses. Começaria então, aqui não só para Dante mas para toda a antiguidade clássica, a “carreira” de fraudes de Ulisses, que fez com que tal cavalo chegasse à cidade de Tróia como um presente. No entanto, por mais que a concepção dessa arma de guerra tenha sofrido o julgamento de ser uma grande fraude, devemos considerar que, para os contemporâneos ao episódio, foi um ato de astúcia e sabedoria, virtudes de um grande herói e das quais gozava Ulisses.

Além do clássico episódio do "presente de grego”, Dante poeta prossegue com a narrativa criando um destino para o herói diferente daquele considerado pela tradição mitológica grega, na qual teria Ulisses morrido com avançada idade, exilado na cidade de Etólia ${ }^{12}$. Segundo o autor da Comédia, continuara Ulisses em suas atividades fraudulentas a ponto de induzir seus companheiros de navegação a seguirem em busca do hemisfério austral, desconhecido do mundo de então, a fim de atingir a montanha do Purgatório. De acordo com Dante, Ulisses, que por uma vontade, um impulso em querer dominar, ou seja, “conhecer”, o que fora estabelecido pela tradição de seu povo como um limite, ultrapassou as colunas de Hércules para navegar oceano afora. Mas devemos considerar também o fato de que as colunas de Hércules representavam um limite estabelecido pelo próprio Hércules ${ }^{13}$, equivalente a Jesus na tradição de então por ser filho do maior dos deuses, ao povo que navegava no Mar Mediterrâneo da antiguidade clássica e, portanto, um alerta para os perigos existentes além desse marco, ou seja, dentro do oceano.

Nem de filho ternura, nem afeta

pena do velho pai, nem justo amor

que alegraria Penélope dileta,

em mim puderam vencer o fervor

que me impelia a conhecer o mundo,

e dos homens os vícios e o valor;

(DANTE, Inferno: Canto XXVI, versos 94-99)

Com tais versos, é chamada a atenção do leitor à importância que assume para o personagem Ulisses a possibilidade de conhecer aquilo que não estava disponível para o homem de sua época ${ }^{14}$,a ponto de ser ele capaz de passar por cima de sentimentos muito mais nobres como o amor do filho, da esposa e do pai. Para Dante, seguindo a perspectiva da tradição filosófica e, sobretudo, da teológica, se o conhecimento não pode conduzir a Deus e não pode engrandecer a alma, ele não pode ser aproveitado e, portanto, será julgado como supérfluo. E por trás da idéia de supérfluo, aquilo além do necessário, está a incontinência, ou melhor, a gula. Além disso, Ulisses deu uma importância muito maior à vontade de querer descobrir os mistérios do hemisfério desconhecido - assim como a montanha do Purgatório, à qual se remete o verso 99 da citação anterior quando apresenta a idéia dos valores dos homens e de seus vícios, os quais são compensados na subida de tal montanha - do que aos sentimentos mais nobres representados pelo amor familiar.

\footnotetext{
12 GUIMARÃES, pág. 313.

${ }^{13}$ Filho de Zeus, que, na mitologia grega, depois de cumprir um dos seus doze trabalhos como semi-deus, deixou uma lembrança de sua passagem pela Líbia ao erguer os rochedos de Ceuta e de Gibraltar. (GRIMAL, pág. 211)

${ }^{14}$ Século VIII a. C.
} 
O “crime” do glutão é ultrapassar os limites que nós guardamos zelosamente e que são definidos pelos nossos instintos mais primitivos: fome, território pessoal - ou seja, sobrevivência. (PROSE, pág. 89)

Ora, mas se Dante também ousou viajar por caminhos não disponíveis aos mortais para conhecer o que estava além de suas capacidades, porque a condenação de Ulisses? É aqui que entra a diferença dogmática entre essas citadas “vontades de conhecimento" adotadas pelo autor da Comédia: para a razão, leia-se conhecimento que conduz à razão, não existe limite se direcionada à busca do Deus cristão. Assim como foi dado a Dante, no mundo ficcional, viajar pelos mundos não permitidos aos seres viventes, tratava-se de uma viagem de aprendizado para a aplicação de sua fé ${ }^{15}$, diferente da viagem de Ulisses. Portanto, Ulisses fora guloso em querer conhecer mais que o permitido uma vez que tal conhecimento se aplicaria somente para saciar sua própria sede de conhecimento, com um agravante - a falta de fé.

Deu o herói vazão contrária aos impulsos de sua racionalidade quando quis se enriquecer de conhecimento. Contrária no sentido de terem a inteligência e a sabedoria a função de conter os impulsos negativos causados pela curiosidade e não de instigá-la mais e mais. Ainda nesse sentido, Ulisses, quando rumou a caminho do Oeste e ultrapassou as colunas de Hércules, seguiu em direção ao sol poente, contrariando, assim, as forças da natureza ao não querer se privar da luz solar. Cabe lembrar que a idéia de luz, sobretudo a divina, é o principal referencial simbólico para a noção de razão e sabedoria; e Ulisses, quando a seguiu, contrariou tanto a tradição de sua época - que impôs as barreiras simbolizadas pelas montanhas chamadas colunas de Hércules - quanto os limites naturais, que dosam a quantidade de luz a ser irradiada pelo sol a todos os homens. Portanto, sob o viés dantesco, mereceu a morte, mas levou também consigo os marinheiros que o acompanhavam desde as aventuras narradas na Ilíada e na Odisséia.

“Pois está escrito: Destruirei a sabedoria dos sábios e rejeitarei a inteligência dos inteligentes. Onde está o sábio? Onde está o homem culto? Onde está o argumentador desse século? Deus não tornou louca a sabedoria deste século? Com efeito, visto que o mundo por meio da sabedoria não reconheceu a Deus na sabedoria de Deus, aprouve a Deus pela loucura da pregação salvar aqueles que crêem.” (BÍBLIA, 1 Coríntios 1,18-21)

Mas Ulisses não é punido solitariamente dentro da chama infernal. Está com ele Diomedes, seu companheiro em vida tanto na guerra de Tróia como na superação das colunas de Hércules. O mesmo Diomedes que roubou a estátua da deusa grega Palas Atena da cidade de Tróia quando de sua derrota para os gregos no episódio do cavalo de madeira. Eis aqui mais um referencial simbólico de sabedoria, além daquele representado pela luz solar, que sofreu um tipo de apropriação indevida. A estátua roubada representava a proteção da deusa à cidade de Tróia, mas por outro lado, a própria deusa simbolizava a sabedoria ${ }^{16}$, a qual Ulisses e Diomedes visavam em sua viagem oceano adentro. Portanto, a luz da sabedoria que os instigou à gula de conhecimento, este além do permitido e para um uso sem fé, é a mesma que agora os consome em forma de chama levando em conta a Lei do Contrapasso. Se essa chama for pensada segundo os preceitos de tal Lei, seria ela o extremo da luz da razão a qual tanto almejou o herói e que agora o devora no círculo dos fraudulentos no Inferno.

É de se atentar, no entanto, que toda tradição filosófica considera inerente ao ser humano saber julgar os seus próprios atos, saber distinguir entre o bem e o mal. Apesar disso, para a tradição católica da qual faz parte Dante, tal capacidade não basta para que haja a salvação daquele homem que soube avaliar sua conduta. É preciso que haja o arrependimento sincero e a vontade de ser salvo.

Apesar disso, devemos admitir que também na alma existe qualquer coisa contrária ao princípio racional, qualquer coisa que lhe resiste e se opõe a ele. (ARISTÓTELES, pág. 264)

Seguindo a partir da citação acima, é necessário lembrar do Pecado Original e de suas relações com o que está sendo estudado. Sabe-se que tal pecado consistiu na extrapolação de um limite também imposto por Deus, neste caso o do Antigo Testamento Bíblico. Eva, a mãe de todos os homens e mulheres, sucumbiu à curiosidade provocada pela serpente e comeu o único fruto proibido do Paraíso para ter acesso ao conhecimento do bem e do mal. Um ato guloso no sentido físico, pela não-necessidade em alimentar-se de tal fruto, visto que existiam vários outros; e guloso também no sentido intelectual, porque ter a faculdade de “ser como Deus, conhecendo o bem e o mal” $(G e 3,5)$ não era necessário àqueles que viviam em perfeita harmonia no Paraíso pré-cristão. Cabe, portanto, a aproximação do Pecado Original com o crime de Ulisses porque em ambas as narrativas, a bíblica e a dantesca, existe a idéia de uma extrapolação da "justa

\footnotetext{
${ }^{15}$ Ver Purgatório, Canto XVIII, v.4, no qual Dante não teme assumir a “sede” de saber por estar seguro de sua fé.

${ }^{16}$ GUIMARÃES, Ruth. Dicionário da Mitologia Grega. $1^{a}$ Edição. São Paulo: Cultrix, 2002. Pág. 80.
} 
medida”, aquilo que no contexto do presente estudo se interpreta como sendo o necessário à sobrevivência, em relação ao alimento, e o necessário à sabedoria, em relação ao conhecimento.

Nas ações humanas, a idéia de justa medida equivale à moderação e à temperança, ou seja, às virtudes que se contrapõem ao excesso. E para que seja possível um distanciamento do exagero, se faz necessário que os homens controlem os seus impulsos desejosos através da razão ${ }^{17}$, aquela mesma que na visão teológica deve nos impulsionar a Deus. Mas o que acontece tanto no episódio bíblico como na narrativa de Dante é a razão sendo usada para uma aproximação indevida de Deus, uma tentativa de igualar-se a Ele quando se quer possuir um conhecimento vetado. E é exatamente essa tentativa de ser igual a Deus que os aproxima, tanto Ulisses e Diomedes quanto Adão e Eva, de Lúcifer - o anjo-caído.

\section{A gula espiritual}

Entramos agora no círculo da Giudeca, onde são punidos os traidores de seus próprios benfeitores, o pior tipo de traição, digna apenas das piores almas. Lá se encontra Lúcifer, o famoso anjo-caído da tradição católica que se rebelou contra Deus ao exaltar sua soberba e sua vaidade num desejo de se igualar ao Criador.

Depois de interpretados como gulosos e incontinentes os atos de Ulisses, chega a vez de pensar os atos de Lúcifer e de como os seus pecados cometidos diretamente contra Deus podem ser também vistos como gula, desta vez sob o aspecto de gula chamada espiritual. Mas para começar a tratar de Lúcifer, tanto como personagem dantesco quanto como figura de importância crucial para a tradição judaico-cristã, se faz necessária uma visão sobre sua origem, bem como sobre sua representação para o mundo ocidental.

Desde os primeiros livros da Bíblia, a menção a um adversário de Deus já era feita, mesmo que para a tradição judaica o deus Javé fosse uma divindade absoluta e o mal só existisse por uma vontade sua. Mas as referências ao espírito maligno sempre estiveram no texto bíblico; seja por metáforas, como a da serpente que induziu Adão e Eva ao Pecado Original (Ge 3,5), ou mesmo de forma explicita como o próprio "inimigo" relatado em Ezequiel 36,2. Em conseqüência disso, e posteriormente pela substancial mudança na representação do mal com o advento do cristianismo ${ }^{18}$, permanece conhecido e muitas vezes repetido o episódio relatado em alguns versículos bíblicos nos quais se fala da queda daquele que seria o mais belo entre todos os anjos, mas que fora expulso do paraíso por sua vontade de se equiparar ao Criador. No entanto, a aproximação do nome de Lúcifer com o de Satanás, ou Diabo, aparece somente mais tarde, no século III, o que vem gerando contradição justamente pelo significado etimológico de tal nome ${ }^{19}$. E como afirma De Sanctis ${ }^{20}$, Satanás é o próprio espírito do mal, é todo o Inferno e possui todas as suas paixões, é o inimigo direto de Deus. Por outro lado, Lúcifer é a pura ininteligência, é a bestialidade, é o vencido por Deus e condenado a penar dentro do último círculo do Inferno por sua traição.

Mas o relevante em toda essa história é a representação adotada por Dante quando escolheu punir no fundo de tal vala o anjo-caído Lúcifer, que simbolicamente representaria a incorporação desse espírito maligno que desde os primórdios da tradição judaica já se contrapunha a Deus sendo chamado de Satanás, ou "adversário" em hebraico (satan). Para o poeta, a imagem da essência do mal se faz com a figura de uma besta de três faces, que de anjo passou a demônio corporificado, para que esse corpo fosse também passível de punição, dentro do gelo.

\footnotetext{
${ }^{17}$ Devemos considerar também a origem etimológica da palavra razão e seu sentido ético (presente desde o século XII, no latim medieval) através do termo rationabilis, por influência de Aristóteles e da idéia de "justa medida” moral. Ver MURRAY, Alexandre. Razão. In LE GOFF, Jacques e SCHMITT, Jean-Claude. Dicionário Temático do Ocidente Medieval. $1^{\text {a }}$ Edição. Bauru: EDUSC; São Paulo: Imprensa Oficial do Estado, 2002.

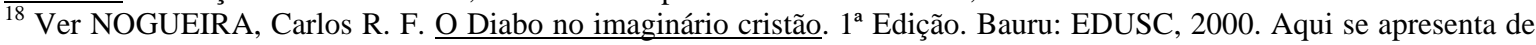
forma detalhada como o cristianismo reinterpretou e afirmou a figura do Mal e como as igrejas cristãs fizeram uso dessa nova imagem para se firmar na posição de Bem inquestionável.

${ }^{19}$ Defende-se a idéia de que chamar o Diabo de Lúcifer possa ter sido um possível erro de interpretação dos versículos Isaías 14,12-14 (Como caíste do céu, ó estrela da manhã, filho da alva! Como foste lançado por terra, tu que debilitavas as nações! Tu dizias no teu coração: "Eu subirei ao céu; acima das estrelas de Deus exaltarei o meu trono e no monte da congregação me assentarei, nas extremidades do Norte; subirei acima das mais altas nuvens, e serei semelhante ao Altíssimo”.) pelo fato de em nenhum momento a Bíblia citar Satanás como Lúcifer. Parafraseando alguns estudos bíblicos que defendem a contextualização deste versículo, que na verdade trata do rei dos babilônios e não do Diabo, entende-se o porquê de muitos não aceitarem a ligação do nome Lúcifer (em hebraico helel, que significa "estrela da manhã”) ao de Satanás, fato que se deu pela divulgação de uma tradução feita ao latim na qual foi empregado o termo lucifer com o sentido de "aquele que carrega a luz".

${ }^{20}$ DE SANCTIS, Francesco. Il canto XXXIII dell’Inferno. In Letture Dantesche. $1^{\text {a }}$ Edizione. Firenze: Sansoni Editore, 1964. Pág. 631.
} 
Mas foi o meu assombro inda crescente

quando três caras vi na sua cabeça:

(DANTE, Inferno: Canto XXXIV, versos 37 e 38)

No Inferno de Dante, Lúcifer ocupa lugar de destaque uma vez que está localizado - ou melhor, preso no gelo - exatamente no centro de tal câmara e faz as vezes de rei do lugar, apesar de também ele estar condenado a cumprir uma pena de duração eterna assim como todos os outros punidos nos vários círculos e, como eles, sofrer com sua pena. Suas três faces horrendas seriam a oposição às virtudes da Santíssima Trindade divina. Sua terrível repugnância, uma compensação baseada na Lei do Contrapasso à sua beleza angelical, a qual foi relatada como a maior de todas, "Se belo foi quão feio ora é seu modo" (DANTE, Inferno: Canto XXXIV, verso 34). Suas asas de morcego, uma contraposição às belas asas angelicais que possuiu; com o apoio da imagem de que os morcegos são constantemente associados a chupadores de sangue, assim como faz Lúcifer ao mastigar certos pecadores.

Como o guloso Cérbero, cão guardião do círculo infernal dos gulosos, o Lúcifer dantesco possui três bocas, usadas por ele na punição daqueles que seriam, para Dante, os maiores traidores da história: Judas, Brutus e Cássio ${ }^{21}$, que assim como Lúcifer traíram seus grandes benfeitores. Dessa maneira, o anjo-caído mastiga incessantemente cada um desses pecadores de forma violenta e, para ser coerente com suas atitudes, bestial. Uma bestialidade canina, típica do animal que na Idade Média era constantemente associado à gula e à ira (LIBELLUS, tópico 39), como descreve Nogueira em seus estudos sobre a representação da figura do mal no imaginário cristão.

O Diabo assume outras e variadíssimas formas animais, como a de um touro, gato, cavalo, porco, veado, camundongo ou mosca. Mas a sua aparição como um cão, e um cão preto - a cor denunciando a presença demoníaca -, ocupa o segundo lugar na preferência dos relatos. Leão, bispo de Chipre, conta que um diabo saiu de um possesso sob a forma de um cão preto. [...] Collin de Plancy, em seu Dicionário infernal, conta que, ainda no século XIX, nos Países Baixos, era costume expulsar os cães das igrejas e inscrever à porta da casa do Senhor: “Os cães, fora do templo de Deus”. (NOGUEIRA, pág. 68-69)

Esse ato de extrema raiva é comparável à ferocidade com a qual o Conde Ugolino della Gherardesca, personagem de alta relevância dentro dos Cantos XXXII e XXXIII, rói a nuca de seu grande inimigo e traidor no círculo da Caína, o arcebispo Ruggieri.

e como um pão morde-se na agonia

da fome, um no outro seus dentes meteu

onde o crânio da nuca se inicia.

(DANTE, Inferno: Canto XXXII, versos 127-129)

O Conde, num impulso de querer dominar politicamente a cidade de Pisa, da qual era cidadão, passou por cima de valores como amizade e parentesco e traiu aqueles dos quais sentia certa ameaça, sendo condenado em vida a padecer de fome, em contraposição à sua grande sede de controlar sua cidade. Com isso, compara-se tanto no pecado como na condenação a Lúcifer, visto que também se encontra parcialmente congelado como o anjo-caído. E se for pensado como se reflete a Lei do Contrapasso nesses personagens, ambos foram privados daquilo que mais almejaram antes de sua condenação: Poder. E por essa fome de poder, os dois mastigam caninamente tais traidores, sejam estes responsáveis diretos ou não por seus crimes e suas condenações.

Mas pensar as ações de Lúcifer - um anjo transformado em demônio - sob o prisma da incontinência, como foi feito com Ciacco e Ulisses, talvez não seja de legitimidade relevante para um estudo filosófico, já que quando Aristóteles pensou tal definição estava se referindo ao espírito humano e à sua natureza cheia de desejos e vontades manifestados pelo nosso intelecto. Mas visto que este se trata de um estudo literário, no qual o próprio Lúcifer não passa de um personagem mítico representado, interpretar seus atos de acordo com os parâmetros usados para pensar atos humanos se torna válido. Também porque, segundo a tradição cristã com a qual compactua Dante, está em Lúcifer a origem de todo o mal e de todos os pecados como a Igreja os concebe. Seria a incontinência uma das “filhas” desse espírito maligno que Lúcifer possui, portanto legítima enquanto projetada nas suas ações. Seria uma conseqüência de suas atitudes imoderadas, que se reflete nos homens também na forma de um não saber mensurar a quantidade justa daquilo que se necessita, seja em forma de alimento ou de procriação da espécie.

\footnotetext{
${ }^{21}$ Judas Iscariotes, traidor de Cristo, que segundo os Evangelhos o vendeu aos fariseus por 30 moedas de prata; Brutus, traidor de Júlio César, que tinha lhe dado poder e fama; e Cássio, general romano também traidor de Júlio César, igualmente seu benfeitor como de Brutus.
} 
Apesar de originariamente a idéia de incontinência ser aplicada à questão sexual e alimentar - como já foi abordado em outra oportunidade, juntamente com o debate sobre a questão de como essa poderia ser projetada em outros contextos -, aqui entra mais uma possível leitura para tal conceito, sempre lembrando que a incontinência aplicada à alimentação nos remete à idéia de que para não entrar no crime da gula o exagero deve ser aproveitado, se é que isso é possível quando se trata de gula física. Como já foi dito, os atos de Lúcifer contra Deus são normalmente associados aos pecados da vaidade e da soberba, mas querendo o anjo - que já era o mais belo entre todos - se igualar a Deus, podemos interpretar seu ato como guloso por não ter ele o que fazer com tanto poder a não ser posteriormente se contrapor ao Criador para Dele se tornar um grande inimigo, levando-se em conta o caráter monoteísta da religião católica, na qual não se admite mais de um Deus. Mas vale lembrar que a tradição cristã não costuma hierarquizar os pecados pelo fato de um sempre conduzir a outro, não existindo melhor ou pior. Com isso, podemos encarar a soberba de Lúcifer principiada por sua gula de poder, por sua vaidade exaltada pelo poder que ele já possuía como "condutor da luz".

É de se atentar ao detalhe de que a gula é normalmente interpretada como um pecado da carne, mas que aqui é posto como um problema espiritual de Lúcifer por ele não ser possuidor de um corpo como o humano. Em Lúcifer, esse desejo desmedido e irracional de possuir tanto poder quanto Deus transforma-se em uma gula espiritual porque, como um anjo, possuía somente essência e não matéria. Mas dentro da sua condenação como rebelde e traidor passou a possuir essa matéria, a mesma constituída para sofrer fisicamente sua pena e na qual se apoiaram Dante e Virgílio para sair da câmara infernal e chegar ao hemisfério desconhecido.

Tomei-lhe o colo, como me pediu,

e, de tempo e lugar, quando bem postas

as condições, e altas as asas, viu,

de Dite se agarrou às hirsutas costas;

de tufo em tufo foi descendo então

entre o pêlo e as congeladas crostas.

(DANTE, Inferno: Canto XXXIV, versos 70-75)

A gula espiritual de Lúcifer, ou seja, o desejo de querer devorar aquilo que não se aplica ao lugar onde ele se encontrava, se reflete naquilo que podemos chamar de gula de mundo por querer o ex-anjo ter tanta influência sobre mortais e imortais quanto Deus. E esse desejo não cessou. Porque apesar da irracionalidade da besta Lúcifer ser punida no fundo do Inferno, o seu espírito maligno continua desencaminhando aquelas almas do mundo terreno privadas da luz da racionalidade que, como foi debatido, deve conduzir ao Criador. A gula de mundo que ele teve ao se rebelar contra seu próprio Benfeitor é a mesma que continua tendo agora: vencido por Ele, mas irradiando a sua própria bestialidade por todos os círculos do Inferno e por fora dele, para que assim consiga arrebanhar e escravizar almas ainda encarnadas para seu reino infernal através dos pecados quando essas forem privadas de seus corpos. Um ato continuamente guloso por querer sempre mais: almas, poder e influência.

“Gula é o prazer de devorar, o puro devorar pelo devorar, o devorar como atividade criadora de realidade.” (FLUSSER, pág. 125)

É o querer devorar o mundo. Nesse sentido, é comum encontrarmos denominações representando o Diabo como "Príncipe desse mundo"22, leia-se o mundo material, pelo fato de estar o seu poder de persuadir os homens associado ao apego que estes tem à matéria.

[...] o Diabo do qual foge [o homem medieval] é um demônio que o tenta e seduz a fim de induzi-lo a pecar; a comunidade a que pertence é antes de tudo uma comunidade de pecadores. (CASAGRANDE, pág. 337-338)

Com isso, entende-se a origem de todos os tipos de gula como oriundas do maior de todos os atos gulosos, o de Lúcifer. Tanto a física do glutão Ciacco, que procurava saciar seus desejos e seus apegos carnais com exagero de comida, quanto a intelectual do herói Ulisses, que por impulso buscou conhecer mais do que lhe fora permitido enquanto homem não dotado de fé e, portanto, não podendo fazer uso de tal sabedoria dentro da visão católica de Dante. Temos o nascimento da gula provocado nada menos do que por

\footnotetext{
${ }^{22}$ Como Martin Lutero propõe de modo intimidador em 1525. Período posterior a Dante, mas baseado na tradição vigente desde a época do poeta. Apesar da divisão no cristianismo provocada por Lutero, a representação do mal continuou tão forte ou mais do já era nas vindouras religiões evangélicas.
} 
um ato guloso em sua origem e que continuou guloso depois de sua punição, fazendo com que os homens, meros objetos vulneráveis a tentações, sucumbam a ela quando não dotados de inteligência suficiente para se dar conta da justa-medida aristotélica.

\section{Referências Bibliográficas}

AGOSTINHO, Santo. Confissões. $9^{\text {a }}$ Edição. São Paulo: Paulus, 1984.

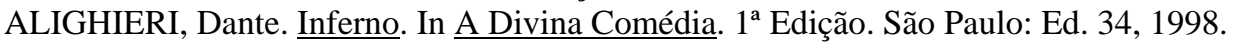

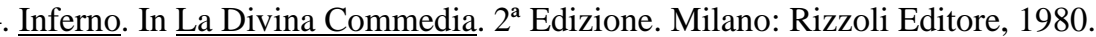

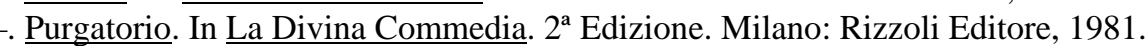

ALVES, Rubem. Lições de Feitiçaria. $1^{a}$ Edição. São Paulo: Loyola, 2000.

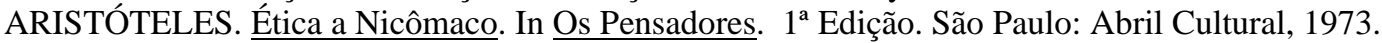

. Poética. In Os Pensadores. $1^{\text {a }}$ Edição. São Paulo: Abril Cultural, 1973.

BOUREAU, Alain. Fé. In LE GOFF, Jacques e SCHMITT, Jean-Claude. Dicionário Temático do Ocidente Medieval. $1^{\text {a }}$ Edição. Bauru: EDUSC; São Paulo: Imprensa Oficial do Estado, 2002.

BÍBLIA. Português. Bíblia de Jerusalém. Nova edição revista e ampliada. São Paulo: Paulus, 2003.

CASAGRANDE, Carla e VECCHIO, Silvana. Pecado. In LE GOFF, Jacques e SCHMITT, Jean-Claude.

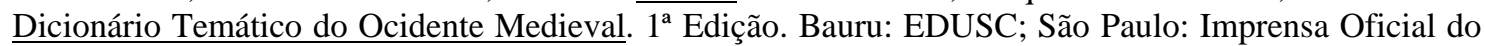
Estado, 2002.

CITTÀ DEL VATICANO. Enciclopedia Cattolica. Prima Edizione. Firenze: Sansoni Editore, 1951. Tomo VI.

CUNQUEIRO. Álvaro. La cocina cristiana de Occidente. 3a Edición. Barcelona: Tusquets Editores, 1999.

DAVIS, John D. Dicionário da Bíblia. Tradução do Rev. J. R. Carvalho Braga. $8^{a}$ Edição. Rio de Janeiro: Junta de Educação Religiosa e Publicações, 1982.

DE SANCTIS, Francesco. Il canto XXXIII dell’Inferno. In Letture Dantesche. $1^{\text {a }}$ Edizione. Firenze: Sansoni Editore, 1964.

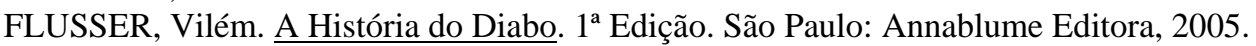

FRANCO Jr., Hilário. A Idade Média, nascimento do Ocidente. $2^{a}$ Edição. São Paulo: Brasiliense, 2004. 1998.

FUBINI, Mario. Il canto XXVI dell’Inferno. In Letture Dantesche. $1^{\text {a }}$ Edizione. Firenze: Sansoni Editore, 1964.

GARCIA, Antônio (Org.). Estudos de Filosofia Medieval. 2a Edição. Petrópolis, RJ: Vozes; São Paulo: Instituto Franciscano de Antropologia: Universidade São Francisco, 1997.

GRIMAL, Pierre. Dicionário de Mitologia Grega e Romana. $1^{a}$ Edição. Rio de Janeiro: Bertrand Brasil, 1997.

GUIMARÃES, Ruth. Dicionário da Mitologia Grega. 1ª Edição. São Paulo: Cultrix, 2002.

LIBELLUS. De natura animalium. Versión galega de Raúl Gómez Pato. http://www.bivir.com/bvbestiario.html

LIBERA, Alain de. Pensar na Idade Média. 1ª Edição. São Paulo: Ed. 34,1999.

LUNGO, Isidoro Del. Il canto VI dell’Inferno. In Letture Dantesche. $1^{\text {a }}$ Edizione. Firenze: Sansoni Editore, 1964.

MEREJKOWSKY, Demetrio. Dante. $1^{\text {a }}$ Edizione. Bolonha: Nicola Zanichelli Editore,1939

MORA, J. FERRATER. Dicionário de Filosofia. $1^{a}$ Edição. São Paulo: Edições Loyola, 2001. Tomo III.

MONDIN, Battista. A grandeza e atualidade de São Tomás de Aquino. $1^{a}$ Edição. Bauru: Edusc, 1998.

MONTANARI, Massimo. Alimentação. In LE GOFF, Jacques e SCHMITT, Jean-Claude. Dicionário Temático do Ocidente Medieval. $1^{a}$ Edição. Bauru: EDUSC; São Paulo: Imprensa Oficial do Estado, 2002.

MURRAY, Alexandre. Razão. In LE GOFF, Jacques e SCHMITT, Jean-Claude. Dicionário Temático do Ocidente Medieval. $1^{\text {a }}$ Edição. Bauru: EDUSC; São Paulo: Imprensa Oficial do Estado, 2002.

NASCIMENTO, Carlos A. O que é Filosofia Medieval. 1ª Edição. São Paulo: Brasiliense, 2004. (Coleção Primeiros Passos)

NOGUEIRA, Carlos R. F. O Diabo no imaginário cristão. 1ª Edição. Bauru: EDUSC, 2000.

PANTEL, Pauline S. As refeições gregas, um ritual cívico. In FLANDRIN, J. e MONTANARI, M. História

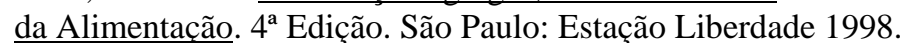

PETROCCHI, Giorgio. Dante e il suo tempo. $1^{\text {a }}$ Edizione. Torino: ERI, 1963. 1964. 


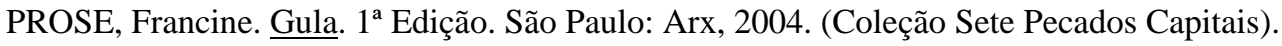

SAPEGNO, Natalino. Storia Letteraria del Trecento. $1^{\text {a }}$ Edizione. Milano-Napoli: Riccardo Ricciardi Editore, 1963.

SOLER, Jean. As razões da Bíblia: regras alimentares hebraicas. In FLANDRIN, J. e MONTANARI, M. História da Alimentação. $4^{a}$ Edição. São Paulo: Estação Liberdade, 1998.

TOMÁS, de Aquino, Santo. Sobre o Ensino (De Magistro). Os sete pecados capitais. $1^{\text {a }}$ Edição. São Paulo: Martins Fontes, 2001.

VERÍSSIMO, Luis Fernado. Gula - O Clube dos Anjos. $1^{\text {a }}$ Edição. Rio de Janeiro: Objetiva, 1998.

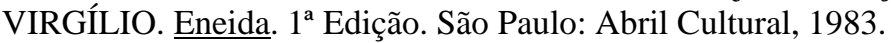

